\title{
KKM TEMATIK KELOMPOK 53 SEBAGAI BENTUK PENGABDIAN KEPADA MASYARAKAT DI DESA PAMANUK KECAMATAN CARENANG KABUPATEN SERANG TAHUN 2021
}

\author{
Fatari ${ }^{1}$, Moh. Darip ${ }^{2}$, Gatot Hartoko ${ }^{3}$, Romani ${ }^{4}$, \\ Anggun Fitriani ${ }^{5}$, Listantiana ${ }^{6}$, Dimas Hardiansyah ${ }^{7}$, \\ $1,2,3,4,5,6,7$ Universitas Bina Bangsa \\ E-mail: ${ }^{1}$ fatari.binabangsa@gmail.com
}

\begin{abstract}
Abstrak
Kegiatan pengabdian pada masyarakat melalui Kuliah Kerja Mahasiswa (KKM) bertujuan untuk Membantu kegiatan pemerintah daerah dalam melaksanakan pembangunan di desa/kelurahan; Menumbuhkan kesadaran masyarakat untuk meningkatkan kualitas kehidupan berbangsa dan bernegara; Menumbuhkan motivasi masyarakat terhadap kegiatan dalam proses pembangunan desa; Membantu mensosialisasikan pencegahan penularan Covid-19 dan sosialisasi akan pentingnya Vaksinasi; Memberikan informasi dan pencitraan keberadaan Perguruan Tinggi Universitas Bina Bangsa. Adapun target yang diharapkan dapat tercapai, yaitu: Dapat menjalankan delapan program kerja yang sudah ditetapkan, memberikan keterampilan dan ikut berperan aktif dalam pengembangan desa. Mahasiswa yang memiliki rasa sensivifitas tinggi terhadap permaslahan dan kesulitan yang dihadapai masyarakat dalam pemberdayaan masyarakat. Menghasilkan mahasiswa sebagai sosok motivator, pemecahan masalah dan pendampingan. Metode pelaksanaan kegiatan ini adalah sosialisasi dan pelatihan dengan melibatkan masyarakat desa Pamanuk secara langsung dan siswa sekolah menengah atas yang ada di desa tersebut. Beberapa hasil yang dicapai dalam kegiatan ini adalah dari beberapa capaian delapan program kerja antara lain; memberikan pemahaman kepada masyarakat tentang kesehatan melalui kegiatan sosialisasi dan penyuluhan, kegaiatan pelatihan computer terhadap siswa sekolah menengah atas, kegiatan pendampingan di bidang UMKM dan bidang Tekonologi Tepat Guna yang dapat dimanfaatkan oleh masyarakat khususnya di desa Pamanuk kecamatan Carenang kabupaten Serang.
\end{abstract}

Kata Kunci: KKM; Pengabdian Masyarakat; Pelatihan; Sosialisasi

\section{Abstract}

Community service activities through Student Work Lectures (KKM) aim to assist local government activities in carrying out development in villages/kelurahan; Growing public awareness to improve the quality of life of the nation and state; Fostering community motivation towards activities in the village development process; Help socialize the prevention of Covid19 transmission and socialize the importance of Vaccination; Provide information and imaging of the existence of Bina Bangsa University College. The targets are expected to be achieved, namely: Able to run eight work programs that have been set, provide skills and take an active role in village development. Students who have a high sense of sensitivity to the problems and difficulties faced by the community in community empowerment. Produce students as motivator, problem solving and mentoring figures. The method of implementing this activity is socialization and training by directly involving the Pamanuk village community and high school students in the village. Some of the results achieved in this activity are from the achievements of eight work programs, including; provide understanding to the public about health through outreach and counseling activities, computer training activities for high school students, mentoring activities in the MSME sector and the field of Appropriate Technology that can be utilized by the community, especially in Pamanuk village, Carenang district, Serang district.

Keywords: KKM; Community dedication; Training; Socialization 


\section{PENDAHULUAN}

Dalam Undang-undang tahun 2012 Tentang Pendidikan Tinggi, disebutkan bahwa pengabdian kepada masyarakat merupakan kegiatan sivitas akademika dalam mengamalkan dan membudayakan ilmu pengetahuan dan teknologi untuk memajukan kesejahteraan umum dan mencerdaskan kehidupan bangsa. Program pengabdian kepada masyarakat yang dilaksanakan oleh Perguruan Tinggi (PT) adalah salah satu dari implementasi Tridharma Perguruan Tinggi. Program ini dilaksanakan dalam berbagai bentuk misalnya: pendidikan dan pelatihan masyarakat, pelayanan masyarakat dan kaji tindak dari IImu Pengetahuan dan Teknologi (Iptek) yang dihasilkan oleh Perguruan Tinggi. Tujuan program ini adalah menerapkan hasil-hasil Iptek untuk pemberdayaan masyarakat sehingga menghasilkan perubahan pengetahuan, keterampilan, dan sikap dari kelompok masyarakat sasaran (Noor, 2010).

Kuliah Kerja Mahasiswa (KKM) merupakan salah satu bentuk kegiatan pengabdian masyarakat oleh mahasiswa dengan pendekatan lintas keilmuan dan sektoral pada waktu dan daerah tertentu. KKM merupakan kegiatan perkuliahan dan kerja lapangan yang merupakan pengintegrasian dari pendidikan dan pengajaran serta pengabdian kepada masyarakat oleh mahasiswa secara sistematis, berdimensi luas melalui pendekatan berbagai disiplin ilmu, komprehensif dan lintas sektoral. KKM merupakan mata kuliah wajib pada seluruh program studi Sarjana di lingkungan Universitas Bina Bangsa (UNIBA). Inti dari mata kuliah KKM ini adalah pembelajaran sekaligus pengabdian pada masyarakat. Oleh karena itu, seluruh kegiatan yang mengandung nilai pembelajaran dan pengabdian pada masyarakat dapat diakui sebagai KKM. Kegiatankegiatan tersebut dilaksanakan dalam masa KKM pada semester berjalan (Wulansari Sisca dkk, 2020).

Kegiatan Kuliah Kerja Mahasiswa (KKM) Universitas Bina Bangsa tahun 2021 mengambil tema "Pengabdian Kepada Masyarakat pada Revitalisasi Dampak Pandemi Covid19: Kontribusi Unversitas Bina Bangsa (UNIBA) Tahun Akademik 2020/2021. Kuliah Kerja Mahasiswa (KKM) merupakan kegiatan lapangan yang dilaksanakan oleh mahasiswa selama kurun waktu tertentu dan merupakan implementasi Tri Dharma Perguruan Tinggi. KKM diharapkan mampu menganalisis permasalahan dan menfokuskan pada pendampingan dalam rangka mempersiapkan SDM unggul berbasis Ekonomi Kreatif dan bidang-bidang yang lain. Seluruh kegiatan KKM diselaraskan dengan program-program dan rencana strategis pembangunan yang diterapkan oleh pemerintah desa khususnya di desa Mekarsari kecamatan Carenang kabupaten Serang. Pelaksanaan KKM pada tahun 2021 ini berbeda 
dengan tahun sebelumnya karena pada masa sekarang bertepatan dengan Pandemi Covid19. Covid-19 memasuki Indonesia pada bulan Maret 2020. Hal tersebut menyebabkan segala aktivitas menjadi berbeda dan terbatas termasuk kegiatan pengabdian Mahasiswa yaitu Kuliah Kerja Mahasiswa (KKM)

KKM pada tahun 2021 ini dapat dilakukan melalui beberapa macam cara diantaranya KKM Tematik, yang dilaksanakan secara berkelompok kemudian disebar kebeberapa wilayah kecamatan yang ada di provinsi Banten. KKM sebagai salah satu bentuk implementasi dari Tri Dharma Perguruan Tinggi yaitu pengabdian pada masyarakat. Namun KKM juga bisa menjadi peluang implementasi Tri Dharma Perguruan Tinggi bentuk lainnya yaitu pengajaran dan penelitian. Mahasiswa dituntut memiliki kreativitas dan perilaku inovatif guna memenuhi ketiga hal tersebut. Dalam penelitian kali ini penulis ingin mewujudkan pelaksanaan lebih maksimal dengan cara melaksanakan KKM sebagai wujud pengabdian pada masyarakat.

Kegiatan KKM ini lebih menekankan pada peran KKM sebagai wujud pengabdian pada masyarakat. Sehingga diharapkan hasilnya dapat bermanfaat untuk masyarakat serta menjadi perbandingan untuk penelitian selanjutnya.

\section{PENGABDIAN KEPADA MASYARAKAT}

Pengabdian kepada masyarakat merupakan pelaksanaan pengamalan ilmu pengetahuan, teknologi dan seni budaya langsung pada masyarakat secara kelembagaan melalui metodologi ilmiah sebagai penyebaran Tri Dharma Perguruan Tinggi serta tanggung jawab yang luhur dalam usaha mengembangkan kemampuan masyarakat, sehingga dapat mempercepat laju pertumbuhan tercapainya tujuan pembangunan nasional.

\section{TUJUAN}

Tujuan yang hendak dicapai melalui kegiatan pengabdian kepada masyarakat adalah sebagai berikut:

a. Bertambahnya kecepatan proses peningkatan kemampuan sumber daya manusia sesuai dengan laju pertumbuhan pembangunan.

b. Bertambahnya kecepatan upaya pengembangan masyarakat ke arah terbinanya masyarakat yang harmonis serta dinamis yang siap menempuh perubahan-perubahan menuju perbaikan dan kemajuan sesuai dengan nilai-nilai sosial budaya dan normanorma dalam kehidupan masyarakat berkembang dalam kehidupan masyarakat yang berlaku. 
c. Bertambahnya kecepatan usaha pembinaan institusi dan profesi masyarakat sesuai dengan laju pertumbuhan proses modernisasi dalam kehidupan masyarakat itu sendiri.

d. Untuk memperoleh umpan balik dan masukan bagi fakultas dalam rangka meningkatkan relevansi pendidikan, diperlukan adanya ahli-ahli yang memiliki kemampuan secara interdisipliner dan multidisipliner.

\section{RUANG LINGKUP}

Kegiatan pengabdian kepada masyarakat secara umum meliputi ruang lingkup sebagai berikut:

a. Pengembangan ilmu pengetahuan teknologi dan seni menjadi produk yang secara langsung dapat dimanfaatkan oleh masyarakat.

b. Penyebarluasan ilmu pengetahuan, teknologi dan seni budaya menjadi produk yang perlu diketahui dan dimanfaatkan oleh masyarakat. Usaha ini dapat dilakukan melalui berbagai cara seperti memberikan penyuluhan, menyediakan percontohan, memperagakan, dan menerbitkan media publikasi.

c. Penempatan ilmu pengetahuan dan teknologi secara benar dan tepat sesuai dengan situasi masyarakat dan tuntutan pembangunan.

d. Pemberian bantuan kepada masyarakat dalam mengidentifikasi masalah yang dihadapi serta mencari alternatif pemecahannya dengan mempergunakan pendekatan ilmiah.

e. Pemberian jasa pelatihan profesional kepada masyarakat dalam berbagai bidang permasalahan yang memerlukan penanganan secara cermat dengan menggunakan keahlian dan keterampilan yang belum dimiliki oleh masyarakat yang bersangkutan.

\section{KULIAH KERJA MAHASISWA (KKM)}

Menurut buku pedoman Kuliah Kerja Mahasiswa (KKM) tahun2021 Universitas Bina Bangsa yang mendefinisikan bahwa Kuliah Kerja Mahasiswa (KKM) merupakan kegiatan lapangan yang dilaksanakan oleh mahasiswa selama kurun waktu tertentu dan merupakan implementasi Tri Dharma Perguruan Tinggi. KKM diharapkan mampu menganalisis permasalahan dan menfokuskan pada pendampingan dalam rangka mempersiapkan SDM unggul berbasis Ekonomi Kreatif dan bidang-bidang yang lain, menjadi 8 bidang program unggulan antara lain: 
1. Bidang Pendidikan dan Keterampilan;

2. Bidang Ekonomi, Pendampingan UMKM, Koperasi dan Ekonomi Kreatif;

3. Bidang keagamaan;

4. Bidang sosial, Budaya dan Pemberdayaan Masyarakat, serta Lingkungan Hidup dan Penghijauan;

5. Bidang Pemerintahan DesaKelurahan dan Pelayanan Masyarakat;

6. Bidang Teknologi Informasi dan Teknologi Tepat Guna;

7. Bidang Hukum dan Penyuluhan Kesadaran Hukum; serta

8. Bidang Kesehatan dan sosialisasi Pencegahan Covid-19 dan Pelaksanaan Vaksinasi. Adapun tujuan dari kegiatan Kuliah Kerja Mahasiswa (KKM) ini selain tujuan secara umum ada tujuan secara khusus yaitu:

1. Membantu kegiatan pemerintah daerah dalam melaksanakan pembangunan di desa/kelurahan;

2. Menumbuhkan kesadaran masyarakat untuk meningkatkan kualitas kehidupan berbangsa dan bernegara;

3. Menumbuhkan motivasi masyarakat terhadap kegiatan dalam proses pembangunan desa;

4. Membantu mensosialisasikan pencegahan penularan Covid-19 dan sosialisasi akan pentingnya Vaksinasi;

5. Memberikan informasi dan pencitraan keberadaan Perguruan Tinggi Universitas Bina Bangsa.

Harapan yang ingin dicapai dari 8 delapan program kerja serta tujuan tersebut adalah dapat terlaksanya kegiatan terhadap sasaran yang sudah ditentukan, dan hasilnya dapat bermanfaat baik oleh masyarakat setempat maupun bagi mahasiswa.

\section{METODE}

Metode untuk mengatasi permasalahan yang ada di Desa Pamanuk meliputi beberapa tahap, yaitu

1. Persiapan dan pembekalan Mekanisme pelaksanaan kegiatan KKM Tematik dilakukan melalui mekanisme sebagai berikut:

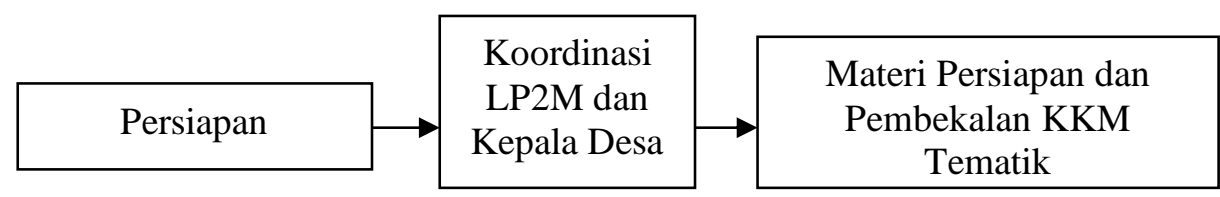




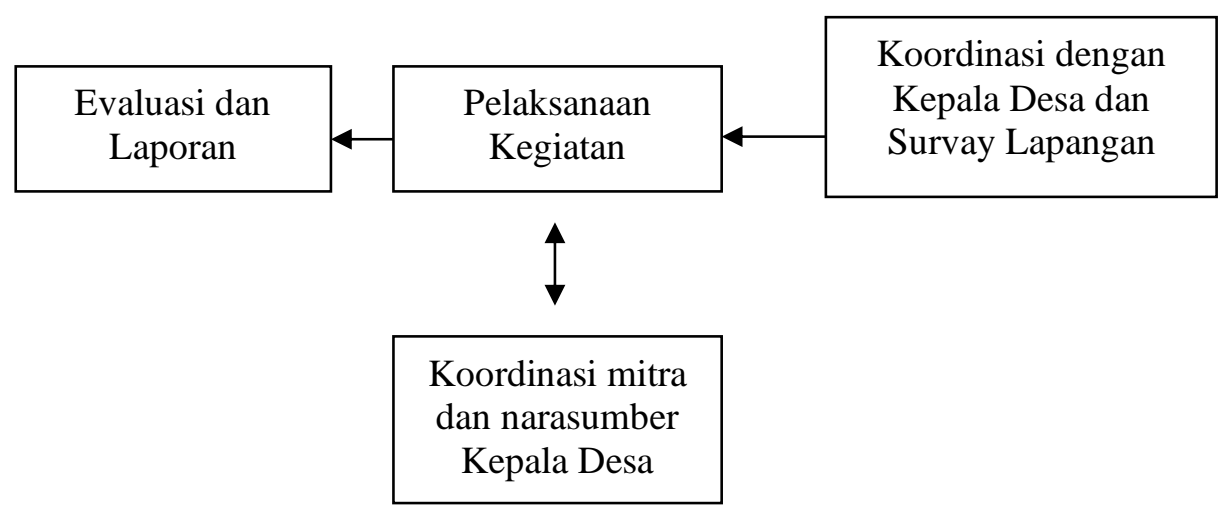

2. Pelaksanaan Langkah-langkah yang akan dilaksanakan untuk mencapai hasil yang diharapkan dari tema KKM Tematik adalah :

a. Metode yang digunakan KKM Tematik di Desa Pamanuk adalah Pendidikan dan pelatihan, sosialisasi, diskusi, Demonstrasi/Percontohan dan Pendampingan serta Pembinaan berkelanjutan.

b. Langkah-langkah operasional yang diperlukan untuk memaksimalkan potensi wilayah Desa Pamanuk dan mengatasi permasalahan yang dideskripsikan pada latar belakang, sebagai berikut :

> Penempatan mahasiswa KKM Tematik yang disebar secara merata ke tiap RT dan Kantor Desa menjadi serta ada satu posko yang dijadikan sebagai home base untuk memudahkan koordinasi;

> Pengorganisasian masyarakat (Kelompok dan Masyarakat umum);

> Sebelum mahasiswa diterjunkan ke lokasi, tim DPL dan perwakilan mahasiswa terlebih dahulu ke lokasi untuk berdialog dengan aparat desa dan tokoh masyarakat, dengan harapan agar kelompok sasaran yang akan menerima program KKM Tematik sudah dapat ditentukan sebelum penerjunan mahasiswa, sehingga saat mahasiswa diterjunkan ke lokasi, masyarakat telah siap untuk bekerja bersama mahasiswa. Untuk mensukseskan kegiatan ini, masyarakat kemudian diberikan penyuluhan, percontohan dan pendampingan, kemudian bersama Masyarakat dan Aparat Desa melakukan evaluasi dan diskusi pembahasan masalah dan penetapan kegiatan bersama Mahasiswa KKM Tematik; 
Adapun Pelaksanaan kegiatan yang meliputi delapan program kerja yang akan dibahas dalam pembahasan hasil KKM Tematik ini desa Pamanuk.

\section{HASIL DAN PEMBAHASAN}

Serangkaian kegiatan yang sudah dilaksanakan oleh KKM kelompok 53, dalam pengabdian kepada masyarakat yang sudah ditetapkan oleh Perguruan Tinggi Universitas Bina Bangsa antara lain:

\section{Bidang Sosial, Budaya dan Pemberdayaan Masyarakat}

Berbagai cara dan upaya dilakukan pemerintah untuk meminimalkan penyebaran virus covid-19, salah satunya dengan diberlakukan PPKM pada semua lapisan masyarakat. Sudah hampir 2 tahun pandemik ini belum berakhir, bermacam bantuan tunai disalurkan dari pemerintah kepada masyarakat yang terkena dampak, khususnya masyarakat berekonomi menengah kebawah. Manfaat bantuan tersebut dirasakan pula oleh sebahagian warga desa Pamanuk. Menurut sekertaris desa Bapak Muhammad Sanwani "Warga kami yang berekonomi rendah dan bermata pencaharian tidak tetap, ada petani, pedagang ataupun kuli bangunan serta yang sudah terdaftar sebagai warga penerima bantuan dari pemerintah merasa terbantu dengan bantuan BLT ini, apalagi dalam kondisi seperti sekarang, yang mana ruang gerak serta aktivitas warga dibatasi menurut aturan dan protokol kesehatan".

Dalam acara pembagian bantuan BLT yang dilaksanakan selama 3 hari (Jumat-Minggu/30 Juli 2021 - 02 Agustus 2021) hadir beberapa mahasiswa Universitas Bina Bangsa yang sedang melaksanakan KKM. Mahasiswa Jurusan Teknik Industri atas nama Romani dalam hal ini sebagai ketua kelompok mengatakan "Kami kelompok 53 sudah 2 pekan melaksanakan KKM di desa ini, lebih lanjut ia mengatakan pelayanan dikantor desa adalah salah satu program kegiatan yang telah kami susun bersama dosen pembimbing lapangan, awalnya kami tidak tahu bahwa akan ada kegiatan pembagian BLT dikantor desa, makanya kami kelompok 53 yang terdiri dari 20 anggota dari berbagai jurusan tidak dapat hadir semua dalam kegiatan ini, karena sebagian anggotanya dialihkan atau dialokasikan kepada kegiatan program kerja yang lain sesuai jadwal yang kami susun".

Menurut sekertaris kelompok 53 mahasiswi jurusan Akuntansi yang biasa disapa Anggun Fitriani yang kebetulan hadir dalam kegiatan tersebut, mengatakan 
"Ada 8 program kerja yang telah ditetapkan dari pihak kampus dan kami sudah menyusun kurang lebih 24 rencana kegiatan yang akan kami laksanakan selama masa KKM, diantaranya ada kegiatan pelatihan pembuatan pupuk organik dari sampah daun kering, pelatihan pembuatan pestisda dari daun sirsak, pelatihan kreasi tangan dari barang-barang bekas, donasi shodaqoh wakaf buku dan alquran serta lain sebagainya, semua sudah kami susun tanggalnya, mudah-mudahan terlaksana sesuai jadwal, " ungkapnya.

Ucapan terima kasih via whatshap datang dari kepala desa yang sekarang sedang nonaktif dinas Bapak Sukri, S. Ag, beliau mengucapkan banyak terima kasih kepada mahasiswa KKM dari Universitas Bina Bangsa yang telah membantu pembagian BLT dikantor desa kepada warganya. Proses penyerahan bantuan ini dilakukan secara teratur berdasarkan jadwal yang sudah ditetapkan oleh desa. Menurut ketua bidang pelayanan kantor desa saudara M. Rizki Rahmawan mahasiswa jurusan Teknik Sipil "Validasi dan cek data dilakukan secara manual dan juga menggunakan system., meskipun anggota kelompok kami yang mendapatkan jadwal pelayanan terbatas, maka untuk antisipasi kerumunan warga kami mengatur beberapa anggota dibeberapa bagian, yaitu bagian kedatangan, bagian cek data dan bagian penyerahan bantuan. Selain itu kami tetap praktekan protokol kesehatan dengan mengatur jarak, pemberian masker dan hand sanitizer kepada warga yang datang ke kantor desa".

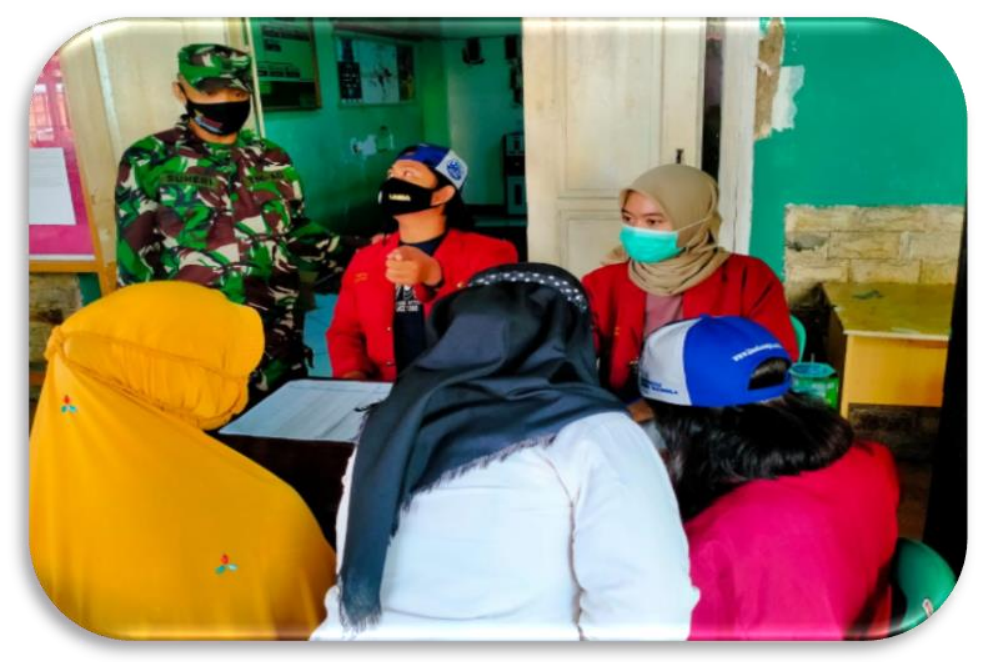

Gambar 1. Membantu Pembagian BLT 


\section{Bidang Pendidikan dan Keterampilan}

Pelaksanaan program bidang pendidikan dan keterampilan yang dilakukan oleh kelompok KKM 53 adalah melaksanakan pelatihan computer bagi siswa Madrasah Aliyah kelas 12 yang ada dilingkungan desa Pamanuk. Program pelatihan yang dilakukan antara lain mengenalkan para siswa dengan program Excel dan Word. Para siswa sangat antusias mengikuti program pelatihan ini, karena lokasi yang terbilang dekat dan pelatihan ini sangat mudah di mengerti. Pada saat pelatihan juga para siswa dibekali dengan modul yang sudah disiapkan oleh pemateri atau narasumber, sehingga para peserta bisa mengikuti pelatihan sambil melihat modul. Modul tersebut sangat membantu bagi para peserta pelatihan karena sangat mudah dipahami. Diakhir file mudul diberikan kepada seluruh peserta pelatihan.

Pelatihan computer ini bertujuan memberikan pemahaman kepada para siswa agar mampu memahami sekaligus mempraktekan dalam kegiatan pembelajaran di sekolah, dan hal yang lebih penting lagi, kelak para siswa mampu menghadapi perkembangan teknologi termasuk di dalamnya teknologi informasi yang sangat erta kaitannya dengan computer. setelah mereka melanjutkan studi ke jenjang pendidikan yang lebih tinggi mereka sudah tidak asing lagi terhadap dunia komputerisasi.

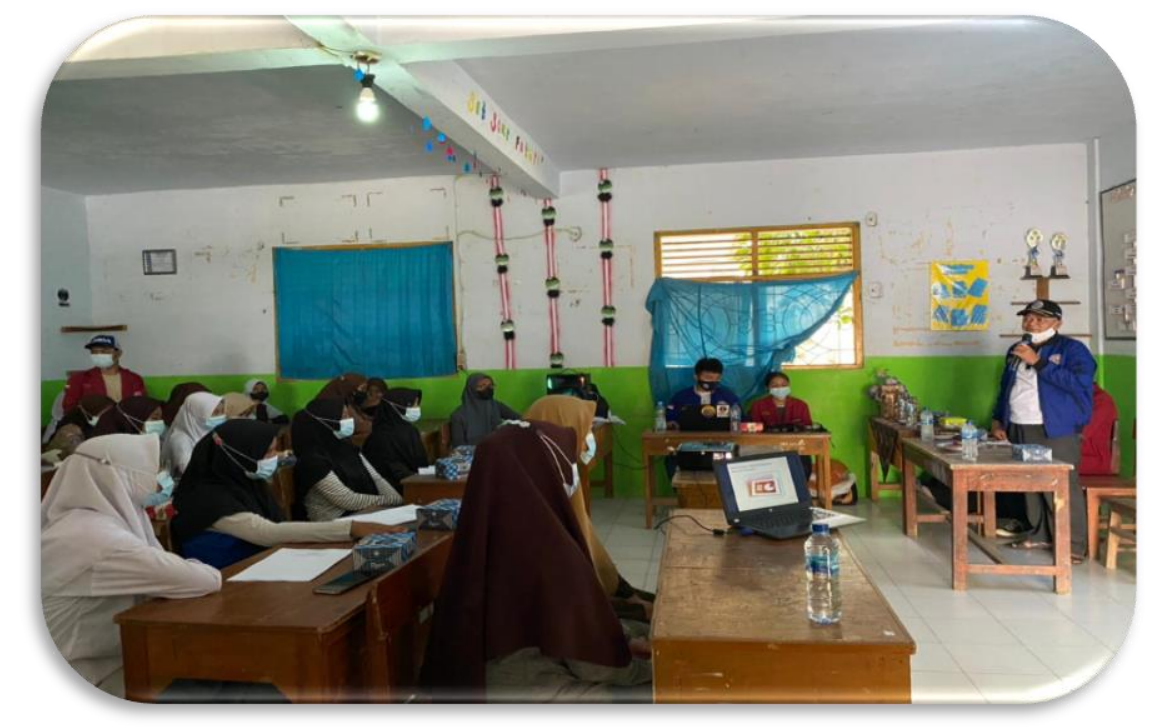

Gambar 2. Sambutan Korcam pada kegiatan Pelatihan Komputer 


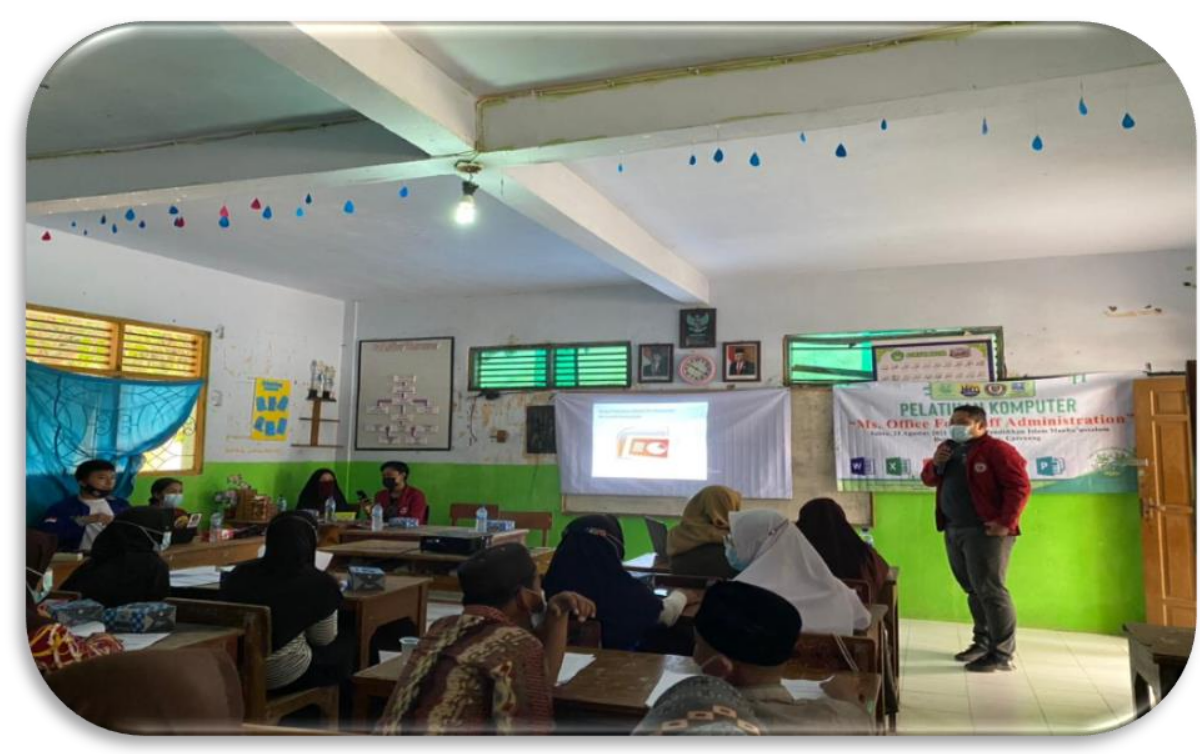

Gambar 3. Penjelasan Materi Pelatihan oleh Narasumber

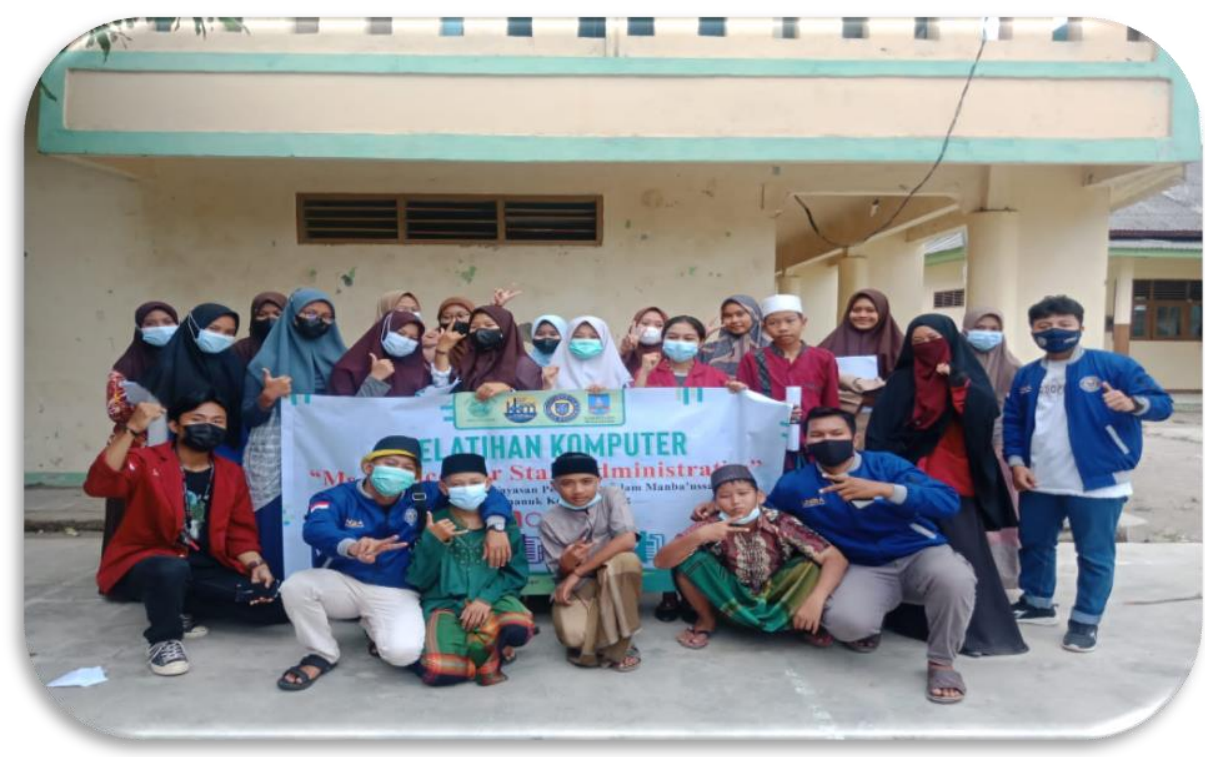

Gambar 4. Foto Bersama dengan peserta Pelatihan

\section{Bidang Hukum dan Penyuluhan Kesadaran Hukum}

Capaian program kerja dibidang Hukum dan Penyuluhan Kesadaran Hukum oleh KKM Kelompok 53 dan kelompok lainnya yang tergabung dalam kegiatan bersama yaitu kelompok 52, 54 dan 55 antara lain menyelenggarakan Penyuluhan Hukum untuk Meningkatkan Kesadaran Hukum Masyarakat di Kecamatan Carenang. Kegiatan ini bertujuan untuk meningkatkan kesadaran masyarakat terhadap norma- 
norma hukum yang berlaku di Indonesia, hal ini dimaksudkan agar masyarakat mematuhi dan mentaati hukum yang berlaku.

Dalam paparan Narasumber, Bapak Encep Saefullah, SH., MH., MM., Adv Dosen Universitas Bina Bangsa, mengatakan hukum adalah aturan yang berisi perintah dan larangan, bersifat memaksa, dibuat oleh Lembaga khusus dan apabila terjadi pelanggaran dikenakan sanksi yang tegas. Faktor penyebab rendahnya kesadaran hukum dimasyarakat adalah mentalitas yang kurang baik dari penegak hukum, fasilitas pendukung proses hukum yang relatif tidak memadai, contoh yang kurang baik dari golongan panutan, tidak adanya Shame Culture dan Guilt Culture, adanya kecenderungan untuk senantiasa kurang melaksanakan beleid, dan lebih mementingkan kelaziman daripada kebenaran. Seperti contoh pelanggaran hukum dalam pengelolaan media sosial yang sering terjadi, menyebarkan berita bohong yang berbau SARA, upload foto tidak senonoh, berbagi foto yang menggambarkan kesadisan, membully di media sosial, pencemaran nama baik. Untuk meningkatkan kesadaran hukum masyarakat maka diperlukan suatu tindakan, pendidikan, kampanye, dan keteladanan, ujarnya.

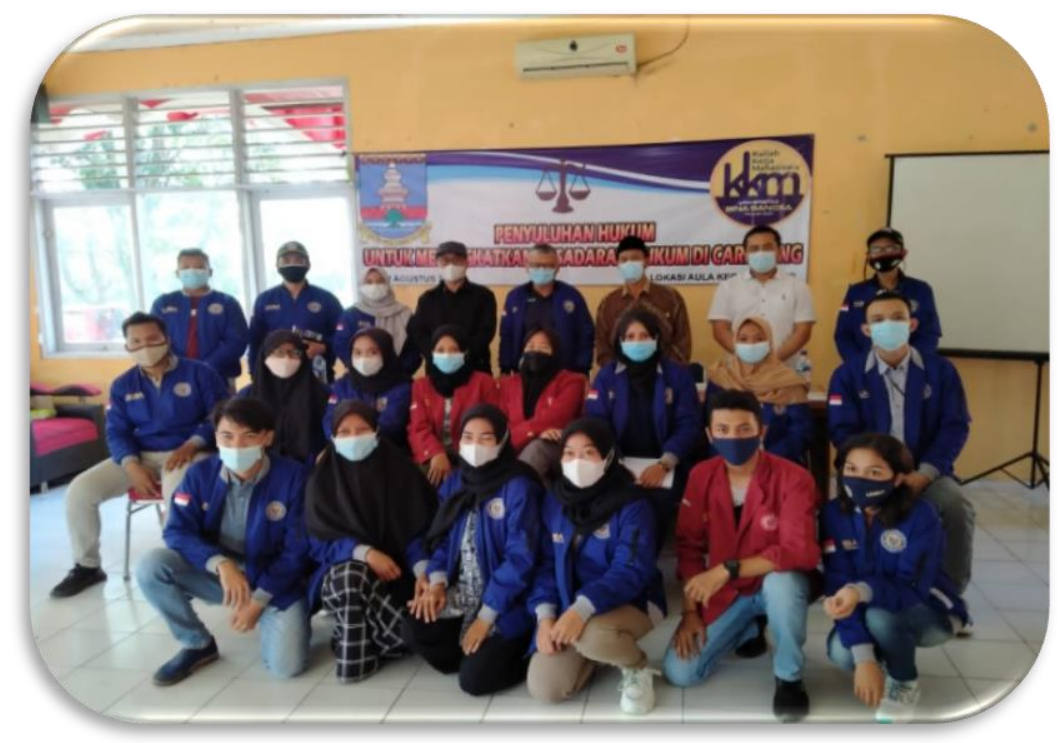

Gambar 5. Penyuluhan Bidang Hukum

\section{Bidang Kesehatan Pencegahan Covid-19 dan Demam Berdarah}

Capaian program kerja dibidang Kesehatan oleh kelompok 53 adalah melalukan sosialisasi Pencegahan Covid-19 dan Demam Berdarah dilingkungan desa 
Pamanuk kecamatan Carenang, sebagai peserta pada acara tersebut adalah perwakilan dari masing-masing RW. dan RT. yang berada di sekitar desa Pamanuk serta beberapa warga masyarakat. Dalam sambutannya bapak Yasin, selaklu Plt kepala desa Pamanuk menyampaikan apresianya atas terselenggaranya acara ini, juga sangat berterimakasih pada KKM 53 yang sudah mengadakan kegiatan ini, harapanya adalah acara ini bermanfaat untuk masyarakat.

Tujuan dari acara ini adalah agar masyarakat khususnya di desa Pamanuk lebih menyadari bahaya dari Covid-19. Antara lain tetap patuh terhadap prokes seperti; mencuci tangan dengan sabun, menjaga jarak, menghindari kerumunan serta menjaga sanitasi lingkungan untuk menghindari Demam Berdarah.

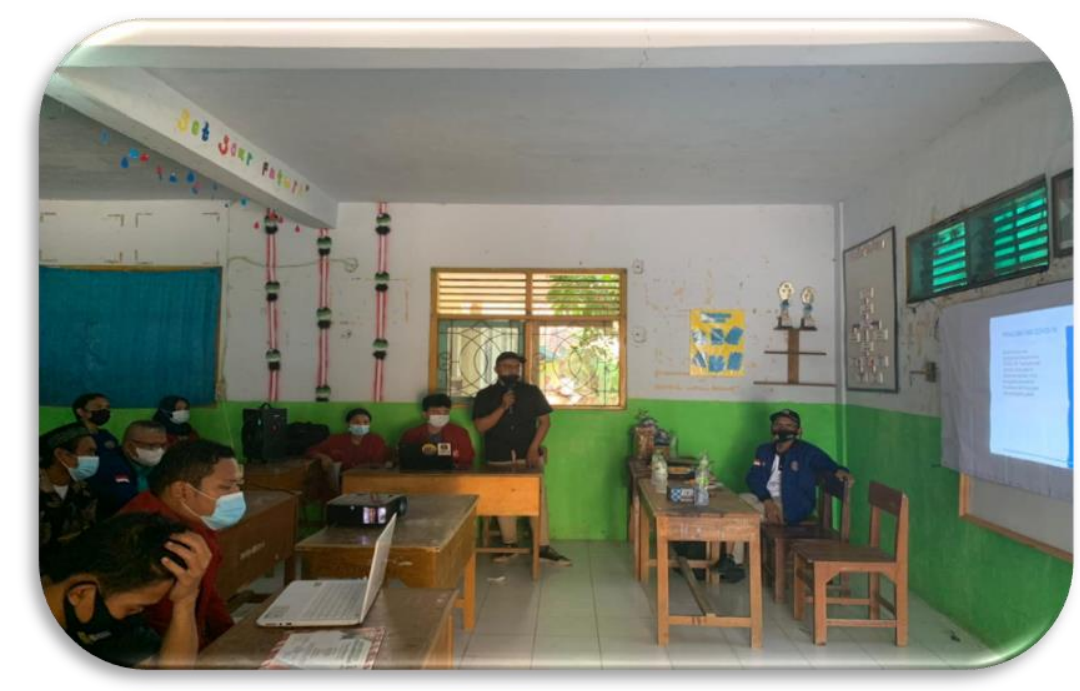

Gambar 6. Penyampaian Materi sosialisasi oleh Narasumber 


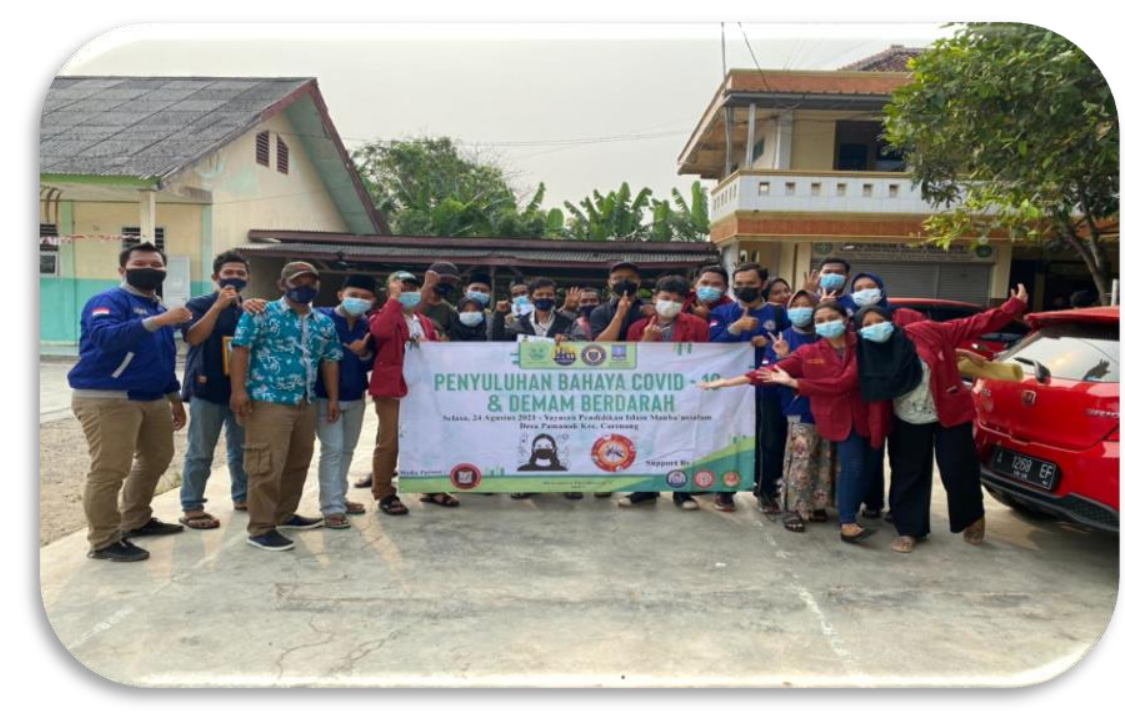

Gambar 7. Foto bersama setelah kegiatan sosialisasi

\section{KESIMPULAN}

Kesimpulan dari kegiatan Kuliah Kerja Mahasiswa (KKM) Kelompok 53 Universitas Bina Bangsa tahun 2021 adalah sebagai berikut:

1. Pelaksanaan Kuliah Kerja Mahasiswa (KKM) Universitas Bina Bangsa tahun 2021 memberikan kesempatan kepada mahasiswa untuk dapat membagikan pengetahuan mereka kepada masyarakat dalam hal pemahaman pencegahan terhadap Covid-19 dan Demam Berdarah, melalui berbagai kegiatan sosialisasi dibidang kesehatan.

2. Kegiatan Kuliah Kerja Mahasiswa (KKM) Universitas Bina Bangsa tahun 2021 dapat memberikan kontribusi yang lebih luas kepada masyarakat melalui kegiatan pelatihan computer bagi para siswa menengah atas agar siswa memiliki keterampilan di bidang ilmu komputer.

3. Capaian lain yang tidak kalah penting adalah mahasiswa KKM 53 melakukan kegiatan sosial antara lain dapat membantu program pemerintah desa Pamanuk dalam pelaksanaan Vaksinasi dan pembagian Bantuan Tunai Langsung (BLT) serta kegiatan penyuluhan di bidang hokum dengan melakukan seminar kesadaran hukum di kecamatan Carenang.

\section{DAFTAR PUSTAKA}

Aribowo, D., Wahyuni, A., Tirtayasa, S. A., Tirtayasa, S. A., Sultan, U., \& Tirtayasa, A. (2018). MASYARAKAT DESA. 202-211. 
Adoe, D. G. H., Pah, J. C. A., \& Tobe, A. Y. (2021). Kkn Tematik Desa FatuseneKecamatan Miomafo Timur Kabupaten Timur Tengah Utara. 4(April), 64-69.

Basuki, K. (2019). Peranan Kuliah Kerja Nyata Sebagai Wujud Pengabdian Kepada Masyarakat Di Tengah Pandemi COVID-19. ISSN 2502-3632 (Online) ISSN 2356-0304 (Paper) Jurnal Online

Kerja, K., Kkm, M., Salah, C.-S., Bentuk, S., \& Tarigan, R. (2020). KULIAH KERJA MAHASISWA (KKM) di MASA PANDEMI COVID-19 SEBAGAI SALAH SATU BENTUK PENGABDIAN KEPADA MASYARAKAT. 2(2), 142-157.

Utami, I. S., Aditya, R., Aryani, N. S., Putri, R. M., Amelia, N., Septiani, T. A., Syifaurrohmah, Widiana, S., \& Amelyani, Y. (2021). Pengabdian Kkm Di Desa Turus Kecamatan Walantaka Kota Serang Dalam Menghadapi Pandemi Covid19 Agar Tetap Produktif. Sarwahita, 18(01), 28-35.

https://doi.org/10.21009/sarwahita.181.3

Undang-Undang No. 12 Tahun 2012, tentang Pendidikan Tinggi

Undang-Undang No. 6 Tahun 2014, tentang Desa

Universitas Bina Bangsa. (2021). Pedoman Kuliah Kerja Mahasiswa (KKM-TEMATIK) Pengabdian Kepada Masyarakat. 